\title{
Agro-morphological Characterization of Cassava (Manihot esculenta Crantz) Collected in the Humid Forest and Guinea Savannah Agro-ecological Zones of Cameroon
}

\section{Temegne Nono Carine ${ }^{1,4 \star}$, Mouafor Boris Igwacho², Ngome Ajebesone Francis ${ }^{3}$}

\author{
${ }^{1}$ University of Yaoundé I, Faculty of Science, Department of Plant Biology, P.O. Box 812 Yaoundé, \\ Cameroon. \\ 2University of Yaoundé II, Faculty of Science Economics and Management, P.O Box 18 Soa, \\ Cameroon. \\ ${ }^{3}$ Institute of Agricultural Research for Development (IRAD), P.O Box 2123 Yaoundé, Cameroon. \\ ${ }^{4}$ University of Bamenda, Higher Technical Teacher Training College, Department of Civil Engineering \\ and Forestry Techniques, P.O. Box 39 Bambili, Cameroon.
}

Emails: 2ibmouafor@yahoo.co.uk,3ngomajebe@ yahoo.com

Article No.: 062716107

DOI: 10.15580/GJAS.2016.7.062716107

Submitted: $27 / 06 / 2016$

Accepted: 07/07/2016

Published: 05/08/2016

${ }^{*}$ Corresponding Author

Temegne Nono Carine

E-mail: nonocarine2003@yahoo.

fr

Phone: (+237)697076 464

\section{Keywords:}

cassava accessions, genetic diversity, agro-morphological descriptors, principal component analysis, multiple correspondence analysis
Background: Cassava (Manihot esculenta Crantz) is an important crop in Cameroon where leaves and tubers are eaten. However, its genetic variability remains unexplored in Cameroon. Local varieties are precious genetic resources because of their diversity. Mastery of this diversity is an important basis for crop improvement through plant breeding programs. Methods: Local cassava accessions (89) were collected mainly in four regions belonging to the Humid Forest and Guinea Savannah agro-ecological zones. These accessions have been planted with the objective to characterize them, based on qualitative and quantitative agro-morphological traits. The experiment was carried out in experimental station of IRAD Nkolbisson, Cameroon.

Results: Significant differences $(p<0.05)$ were observed for all the 14 analysed quantitative traits. Coefficients of variation of quantitative traits range from $11.85 \%$ (number of leaf lobes) to $55.75 \%$ (weight of shoot). Of the 14 quantitative traits studied, 7 had high coefficients of variation (CV $>20 \%)$. The remaining 7 traits exhibit low variations. Root yields of 10 to $13 \mathrm{t} /$ ha was observed with some of the accessions. The Principal Component Analysis for quantitative traits and Multiple Correspondence Analysis for qualitative traits revealed high dispersion of the accessions. On the cluster analysis for qualitative traits the accessions were classified in three groups. The dendrogram with the quantitative traits produced three main cluster groups of the cassava accessions evaluated. Conclusion: This work showed the variation in agronomic traits existing among cassava accessions in the forest and savannah agro-ecological zones of Cameroon that could be exploited to enhance cassava breeding programs. 


\section{INTRODUCTION}

Cassava (Manihot esculenta Crantz, Euphorbiaceae) is the staple food of about 800 million people across the world (FAO, 2000). It is produced mainly for its roots and leaves (Ngome et al., 2013; Temegne et al., 2015a). Cassava is grown in all the five agroecological zones of Cameroon and is one of the most important food crops. Cassava can grow and produce acceptable yields in poor soils with low nutrient available (Temegne et al., 2015a). However, cassava production in Cameroon is still below consumption requirements. In addition, demographic projections forecast an increase in world population. This increase in population growth far exceeds that of agricultural production. The challenge for agricultural research is to contribute to increasing agricultural productivity through improved crop yields and the use of intrinsic capabilities of local accessions tolerance to diseases. To properly use these local varieties, it is imperative to identify them, to characterize them and eliminate duplicates in the collections. Lin (1991) emphasizes that the agro-morphological characterization is fundamental in order to provide information for plant breeding programs. The objective of this work was to characterize local cassava accessions collected in two agro-ecological zones of Cameroon to facilitate development of improved varieties.

\section{MATERIALS AND METHODS}

\section{Plant material}

The plant material (Table 1) was made up of 89 cassava accessions collected between January and March 2015 from the Centre, South and East Regions (Humid Forest agro-ecological zone); and in the Adamawa Region (Guinea Savannah agro-ecological zone). However a few accessions were collected from the Western and Littoral Regions.

\section{Study site}

This study was conducted at the experimental farm of

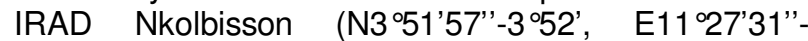
$\left.11^{\circ} 27^{\prime} 36^{\prime \prime}\right)$. The Nkolbisson station is located in the humid forest agro-ecological zone with bimodal rainfall, in the Yaoundé VII Sub Division. The average daily air temperature ranges from $23-24{ }^{\circ} \mathrm{C}$. It is characterized by rainfall from 1600 to $1800 \mathrm{~mm}$ per year. The site is also characterized by haplic ferralsol usually acidic. The area is governed by a Guinean equatorial climate with four seasons: a long rainy season from September to November, a long dry season from December to February, a short rainy season from March to June and a short dry season from July to August (Ngome et al., 2013).

\section{Field trial}

Cassava cuttings of $20-30 \mathrm{~cm}$ in length were planted at a distance of $1 \mathrm{~m}$ by $1 \mathrm{~m}$ in March 2015. Each of the accessions had a total of 20 stands in two lines. Manual weeding and herbicide application were done as required. No fertilizer was applied. Harvesting was done 12 months after planting.

\section{Data collection}

Based on morphological and agronomic descriptors cassava as presented by Fukuda et al. (2010), the quantitative (Table 2) and qualitative (Table 3) parameters were recorded at three, six, nine and twelve months after planting.

\section{Statistical analysis of the data}

Data on qualitative and quantitative characters were analysed separately. For the quantitative traits the statistical analyses were performed only on root yield using the SNK (Student and Newman-keuls) tests at $5 \%$ in order to group the accessions. The average classification was performed only on a character because of the great variability among accessions. The data were processed by principal component analysis (PCA) using Minitab 16 Statistical, SPSS and SAS 9.2 (Statistical Analysis Software) softwares. PCA and correlation matrices are used to explore the links between the quantitative traits, identify and define the main characteristics of groups of accessions. Descriptive statistics (means, standard deviation, minimum, maximum, variance and coefficient of variation) and correlation coefficients analysis were computed for quantitative data. The hierarchical classification tree by UPGMA (Unweighted pair group method with arithmetic mean) automatically created groups of accessions according to the importance of the variables considered. These groups included accessions that have almost the same characteristics from the homogeneity of the elements of a class criterion (Volle, 1981). This clustering method was used for both qualitative and quantitative data. For qualitative data, descriptive statistics, multiple correspondence analysis and clustering analysis were computed.

\section{RESULTS AND DISCUSSION}

\section{Results}

Accessions No. 49 (Green petioles) and 81 (Mbam) were very seriously affected by Cassava Mosaic Virus particularly after six months of planting. These two accessions were eliminated as data collection after six months. 
Table 1: List of various landraces of cassava with their code and source of collection

\begin{tabular}{|c|c|c|c|c|c|c|c|c|c|c|c|}
\hline $\mathrm{N}^{\circ}$ & Accessions & Villages & Regions & $\mathrm{N}^{\circ}$ & Accessions & Villages & Regions & $\mathrm{N}^{\circ}$ & Accessions & Villages & Regions \\
\hline 9 & Polarouge & Belel & Adamawa & 39 & Campo1 & Mva'a 2 & Centre & 69 & Saa & Sa'a & Centre \\
\hline 10 & Tokbanbwgueive & Dana & Adamawa & 40 & Badobo & Tikolo & East & 70 & Mekinda & NsongLong 2 & Centre \\
\hline 11 & Polanoircourt & Belel & Adamawa & 41 & Moanmoan & Nkol ossan & Centre & 71 & Maniocbassa1 ${ }^{\mathrm{er}}-9$ & nd & Centre \\
\hline 12 & Polanoirlong21 & Belel & Adamawa & 42 & Mintourou & Mva'a 2 & Centre & 72 & Ayan & Ayan & Centre \\
\hline 13 & Gladys & Dschang & West & 43 & Ngambada & Soabor & Adamawa & 73 & Campo2 & Mva'a 2 & Centre \\
\hline 14 & Mabong & Sovokong & Adamawa & 44 & Gbalonkpong & Gandong & East & 74 & Ntolbiko & Binguela 1 & Centre \\
\hline 15 & Brownstem & Yambeng & East & 45 & Petiolerouge & Bafia & Centre & 75 & Akourou1 & Ovangoul & Centre \\
\hline 16 & Manimbong & Sangmelima & South & 46 & Afouda & Douayel & Adamawa & 76 & Enouma & Obokoé & Centre \\
\hline 17 & Polanoirlong & Belel & Adamawa & 47 & Ntangna & Mva'a & Centre & 77 & Megong & Megong & South \\
\hline 18 & Bout & Mpemzok & East & 48 & Tougueda & Gbata & Adamawa & 78 & Ntem & Okoukouda & Centre \\
\hline 19 & Sawada & DigouAdamou & Adamawa & 49 & Green petioles & Yambassa & Centre & 79 & Ekweme & Ekweme & South \\
\hline 20 & Gambada & Soagol & Adamawa & 50 & Libogo & Adinkol & East & 80 & Campo18 & Nkol ossan & Centre \\
\hline 21 & Balonkpong & Dana & Adamawa & 51 & Petiolesrouges & Yambassa & Centre & 81 & Mbam1 & Mbam & Centre \\
\hline 22 & Yara & Adinkol & East & 52 & Tuyobo & \begin{tabular}{|l|} 
Bethanie \\
\end{tabular} & East & 82 & Ekekam1 & Ekekam & Centre \\
\hline 23 & Maniocsucré & Soabor & Adamawa & 53 & Gbafdougoa & Bata & Adamawa & 83 & Ekekam2 & Ekekam & Centre \\
\hline 24 & Gambada1 & Boumadjalé & Adamawa & 54 & Redpetiol & Binoum & Littoral & 84 & Maniocbassa & nd & Centre \\
\hline 25 & Mabong1 & Sovokong II & Adamawa & 55 & Fonctionnaire & Mekonkin & Adamawa & 85 & Owona & nd & South \\
\hline 26 & 6mois & Tikolo & East & 56 & Bokito & Bokito & Centre & 86 & Mbidaetmbani & nd & South \\
\hline 27 & Akourakwa & Mpemzok & East & 57 & Gambada2 & Soabor & Adamawa & 87 & Maniocjaune & nd & Adamawa \\
\hline 28 & Guge & nd & Adamawa & 58 & Petiolevert & Bafia & Centre & 88 & Manmbong & Sobou 2 & South \\
\hline 29 & $2^{e}-9$ & nd & Adamawa & 59 & Greenpetiol & Binoum & Littoral & 89 & Nnomewondo & nd & South \\
\hline 30 & Bitoto & Bitoto & South & 60 & Redpetiol & Bokito & Centre & 90 & Makoumba1 & Ndoumalé & South \\
\hline 31 & Nkolossan & Nkol ossan & Centre & 61 & Damouna & nd & Adamawa & 91 & Zieyabomedze & nd & Adamawa \\
\hline 32 & Balbine & MeyosBebeng & South & 62 & Tymere & Koumou & South & 92 & Bitourou & nd & South \\
\hline 33 & Bititi & Boumadjalé & Adamawa & \begin{tabular}{|l|}
63 \\
\end{tabular} & Ntani & Koumou & South & 93 & Minbourou & Mindourou & East \\
\hline 34 & Che & nd & Adamawa & 64 & Ntolo & Ntolo & Littoral & 94 & Ntangnapetiolerouge & Okoukouda & Centre \\
\hline 35 & Madaga & nd & Adamawa & 65 & Yoyolo & Ovangoul I & Centre & 95 & Makoumba2 & Mefomo & Centre \\
\hline 36 & Mraheg & nd & Adamawa & 66 & Akourou & Ovangoul & Centre & 96 & Alotbikon & nd & Adamawa \\
\hline 37 & Gbegueda & Gandoua & Adamawa & 67 & Noumpe & GarouYaka & East & 97 & Afobo & Nkozoa & Centre \\
\hline 38 & Moumpe & GarouYaka & East & 68 & Eboa & Koumou & South & & & & \\
\hline
\end{tabular}

nd: not determined 
Table 2: Qualitative Characters along with their descriptors

\begin{tabular}{|c|c|c|c|}
\hline Evaluation phase & Measured variables & Code & Scoring \\
\hline \multirow{2}{*}{$\begin{array}{l}3 \text { months after } \\
\text { planting }\end{array}$} & color of apical leaves & cal & 3: light green, 5 : dark green, 7: purplish green, 9: purple \\
\hline & $\begin{array}{l}\text { pubescence on apical } \\
\text { leaves }\end{array}$ & pal & $0:$ absent, $1:$ present \\
\hline \multirow{9}{*}{$\begin{array}{l}6 \text { months after } \\
\text { planting }\end{array}$} & color of leaf vein & clv & $\begin{array}{l}\text { 3: green, 5: reddish-green in less than half of the lobe, } 7 \text { : } \\
\text { reddish-green in more than half of the lobe, } 9: \text { red }\end{array}$ \\
\hline & petiole colour & $\mathrm{pc}$ & $\begin{array}{l}\text { 1: yellowish-green, 2: green, 3: reddish-green, } 5: \\
\text { greenish-red, 7: red, 9: purple }\end{array}$ \\
\hline & orientation of petiole & op & $\begin{array}{l}\text { 1: inclined upwards, 3: horizontal, 5: inclined downwards, } \\
\text { 7: irregular }\end{array}$ \\
\hline & flowering & $f$ & $0:$ absent, $1:$ present \\
\hline & shape of central leaflet & scl & $\begin{array}{l}\text { 1: ovoid, 2: elliptic-lanceolate, 3: obovate-lanceolate, 4: } \\
\text { oblong-lanceolate, 5: lanceolate, 6: straight or linear, 7: } \\
\text { pandurate, 8: linear-piramidal, 9: linear-pandurate, 10: } \\
\text { linear-hostatilobalate }\end{array}$ \\
\hline & leaves color & Ic & 3 : light green, 5: dark green, 7: purple green, 9: purple \\
\hline & leaf retention & $\operatorname{Ir}$ & $\begin{array}{l}1: \text { very poor, } 2: \text { Less than average, } 3: \text { average, } 4: \text { better } \\
\text { than average, } 5: \text { outstanding }\end{array}$ \\
\hline & lobe margins & Im & 3: smooth, 5: winding \\
\hline & pollen & po & $0:$ absent, 1 : present \\
\hline \multirow{9}{*}{$\begin{array}{l}9 \text { months after } \\
\text { planting }\end{array}$} & growth habit of stem & ghs & 1: straight, 2: zig-zag \\
\hline & $\begin{array}{l}\text { color of end branches } \\
\text { of adult plant }\end{array}$ & ceb & 3: green, 7: green- purple, 9: purple \\
\hline & $\begin{array}{l}\text { distance between leaf } \\
\text { scars }\end{array}$ & dbls & 3: short $\leq(8 \mathrm{~cm}), 5:$ medium $(8-15 \mathrm{~cm}), 7:$ long $\geq(15 \mathrm{~cm})$ \\
\hline & color of stem cortex & $\operatorname{csco}$ & 1: orange, 2: light green, 3: dark green \\
\hline & color of stem epidermis & csep & 1: cream, 2: light brown, 3: dark brown, 4: orange \\
\hline & color of stem exterior & $\operatorname{csex}$ & $\begin{array}{l}\text { 3: orange, 4: greeny-yellowish, 5: golden, 6: light brown, } \\
\text { 7: silver, 8: gray, 9: dark brown }\end{array}$ \\
\hline & stipule margin & sm & 1: entire, 2: split or forked \\
\hline & prominence of foliar scars & pfs & 3: semi-prominent 5: prominent \\
\hline & length of stipules & Is & 3: short, 5: long \\
\hline \multirow{15}{*}{$\begin{array}{l}12 \text { months after } \\
\text { planting (harvest) }\end{array}$} & fruit & $\mathrm{fr}$ & $0:$ absent, $1:$ present \\
\hline & seeds & $\mathrm{s}$ & $0:$ absent, $1:$ present \\
\hline & levels of branching & $\mathrm{lb}$ & 0: no branching \\
\hline & branching habit & $\mathrm{bh}$ & $\begin{array}{l}\text { 1: erect, 2: } \\
\text { tetrachotomous }\end{array}$ \\
\hline & shape of plant & $\mathrm{sp}$ & 1: compact, 2: open, 3: umbrella, 4: cylindrical \\
\hline & extent of root peduncle & erp & 0: sessile, 3: pedunculate, $5:$ mixed \\
\hline & color of root cortex & crc & 1: white or cream, 2: yellow, 3: pink, 4: purple \\
\hline & root taste & $\mathrm{rt}$ & 1: sweet, 2 : intermediate, 3: bitter \\
\hline & texture of root epidermis & tre & 3: smooth, 5: intermediate, 7 rough \\
\hline & color of root pulp & crp & 1: white, 2: cream, 3: yellow, 4: orange, 5: pink \\
\hline & external color of root & ecr & 1: white or cream, $2:$ yellow, 3 : light brown, $4:$ dark brown \\
\hline & root shape & rs & 1: conical, 2: conical-cylindrical, 3: cylindrical, 4: irregular \\
\hline & cortex thickness & ct & 1: thin, 2: intermediate, 3 : thick \\
\hline & root constrictions & $\mathrm{rc}$ & 1: few to none, 2: some, 3: many \\
\hline & cortex: ease of peeling & $\mathrm{cp}$ & 1: easy, 2: difficult \\
\hline
\end{tabular}


Table 3: Quantitative Characters along with their descriptors

\begin{tabular}{|c|c|c|c|}
\hline Evaluation phase & Measured variables & Code & Scoring \\
\hline \multirow{5}{*}{$\begin{array}{l}6 \text { months after } \\
\text { planting }\end{array}$} & length of leaf lobe & III & $\begin{array}{l}\text { measure three leaves from the middle of the plant, } \\
\text { measure from the intersection of all lobes to the end of } \\
\text { the middle lobe }\end{array}$ \\
\hline & width of leaf lobe & wll & $\begin{array}{l}\text { measure three leaves from the middle of the plant, } \\
\text { measure from the widest part of the middle lobe }\end{array}$ \\
\hline & ratio length/width lobe & $r$ & ratio between length and width was performed with Excel \\
\hline & number of leaf lobes & nll & $\begin{array}{l}\text { assess on five leaves and take the predominant number } \\
\text { of lobes }\end{array}$ \\
\hline & petiole length & $\mathrm{pl}$ & measure two leaves/plant from the middle third \\
\hline \multirow{9}{*}{$\begin{array}{l}12 \text { months after } \\
\text { planting } \\
\text { (harvest) }\end{array}$} & plant height & ph & $\begin{array}{l}\text { measure vertical height from the ground to the top of the } \\
\text { canopy, record measurements from three plants }\end{array}$ \\
\hline & height to first branching & $\mathrm{hfb}$ & $\begin{array}{l}\text { measure vertical height from ground to first primary } \\
\text { branch }\end{array}$ \\
\hline & angle of branching & $\mathrm{ab}$ & measure at first primary branching (3), later divide by two \\
\hline & $\begin{array}{l}\text { number of storage } \\
\text { roots }\end{array}$ & nsr & record from each of three plants \\
\hline & $\begin{array}{l}\text { number of commercial } \\
\text { roots per plant }\end{array}$ & ncr & $\begin{array}{l}\text { record the number of roots from three plants with } \\
\text { length greater than } 20 \mathrm{~cm}\end{array}$ \\
\hline & root yield & ry & measure the weight of fresh roots \\
\hline & weight of shoot & ws & measure the weight of aboveground biomass \\
\hline & total plant biomass & $\mathrm{tpb}$ & weight of roots + weight of aboveground biomass \\
\hline & harvest index & hi & measure on 5 plants \\
\hline
\end{tabular}

Frequency distribution of accessions according to qualitative characters

Only $12 \%$ of local accessions had hair on their apical leaves. Approximately $46 \%$ of accessions had red petioles, $37 \%$ greenish-red petioles, $16 \%$ purple petioles and $1 \%$ yellowish-green petioles (Figure 1). Nearly half of the accessions (45\%) had green leaf vein, $50 \%$ reddish-green $16.09 \%$ reddish-green in less than half of the lobe, $34.48 \%$ reddish-green in more than half of the lobe) and $5 \%$ red. Petioles of most accessions were horizontal (34.48\%) and inclined downwards (26.44\%), $24 \%$ had petioles inclined upward and $14.94 \%$ irregular petioles. Over $90 \%$ of the studied accessions had green leaves (48\% light green, dark green $44 \%$ ) and sweet roots (93\%). Accessions with white (59) and red (27) cortex were predominant. Out of all the accessions studied, $60.92 \%$ had cylindrical, $16.09 \%$ conicalcylindrical, $12.64 \%$ conical and $10.34 \%$ irregular plant shape (Figure 1). 


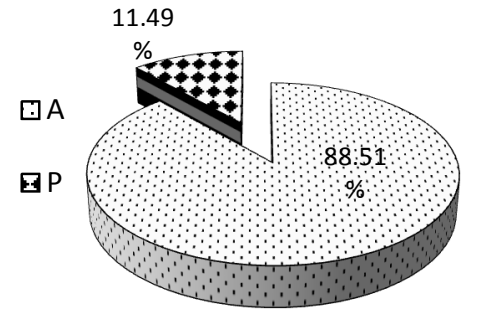

Pubescence on apical leaves

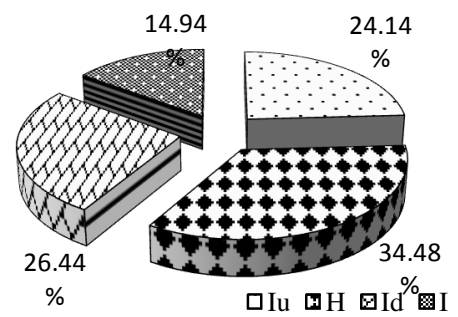

Orientation of petiole

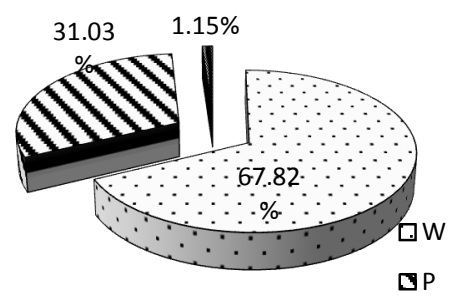

Color of root cortex
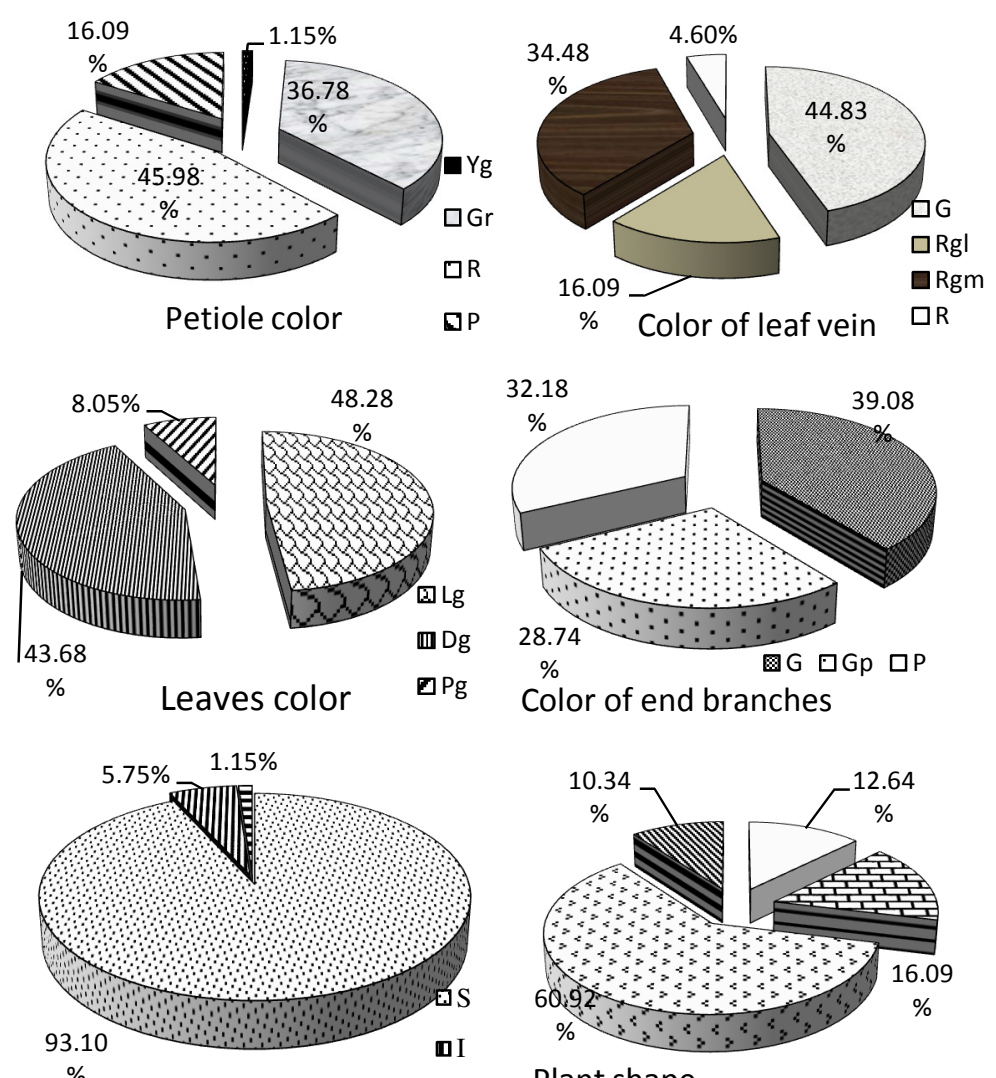

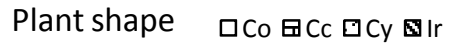

Figure 1: Frequency distribution of accessions on the basis of some qualitative agromorphological traits. Pubescence on apical leaves (A: absent, P: present), Petiole color (Yg: yellowish-green, Gr: greenish-red, R: red, P: purple), Color of leaf vein (G: green, Rgl: reddish-green in less than half of the lobe, Rgm: reddish-green in more than half of the lobe, R: red), orientation of petiole (lu: inclined upwards, H: horizontal, Id: inclined downwards, I: irregular), Leaves color (Lg: light green, Dg: dark green, 7: Pg: purple), Color of end branches of adult plant (G: green, Gp: green- purple, P: purple), Color of root cortex (W: white or cream, Y: yellow, P: pink), Root taste (S: sweet, I: intermediate, B: bitter), Shape of plant (Co: conical, Cc: conical-cylindrical, Cy: cylindrical, Ir: irregular).

\section{Representation of variables of qualitative characters}

Generally, the factors having eigenvalue greater than 1 are retained. The model overview table in SPSS produced on the basis of this criterion 22 factors. But only the first 10 dimensions were presented in Table 4. The objective of Multiple Correspondence Analysis (MCA) is to provide interpretable visualization of complex-variable space. The meaning given to the axes (dimensions) and analysis of proximities between variables and conditions are usually made from the factorial planes. Thus, only the first factorial plan was retained. The first two dimensions (first factorial plan) allow explaining about $32.2 \%$ of the original variance (Table 4). The strongly correlated traits (Table 5, Figure 2) to the first axis (dimension) are levels of branching $(71 \%)$, branching habit $(69 \%)$, shape of plant $(68.8 \%)$, pollen $(55.9 \%)$, flowering $(55.9 \%)$ and shape of central leaflet $(37.3 \%)$. The best represented characters in the dimension 2 are colour of end branches of adult plant $(60.2 \%)$, petiole colour $(55.3 \%)$, colour of leaf vein (54.6\%), colour of root cortex (36.2\%) and orientation of petiole (31.8\%). 
Table 4: The inertia associated with the eigenvalues of qualitative variables

\begin{tabular}{|c|c|c|c|c|}
\hline \multicolumn{5}{|c|}{ Model Summary } \\
\hline \multirow{2}{*}{ Dimension } & Cronbach's & \multicolumn{3}{|c|}{ Variance accounted for } \\
\cline { 3 - 5 } & Alpha & Total (Eigenvalue) & Inertia & \% of Variance \\
\hline 1 & 0.849 & 5.578 & 0.186 & 18.593 \\
\hline 2 & 0.781 & 4.075 & 0.136 & 13.582 \\
\hline 3 & 0.727 & 3.369 & 0.112 & 11.230 \\
\hline 4 & 0.665 & 2.801 & 0.093 & 9.337 \\
\hline 5 & 0.630 & 2.560 & 0.085 & 8.533 \\
\hline 6 & 0.619 & 2.492 & 0.083 & 8.308 \\
\hline 7 & 0.605 & 2.406 & 0.080 & 8.022 \\
\hline 8 & 0.580 & 2.278 & 0.076 & 7.594 \\
\hline 9 & 0.555 & 2.155 & 0.072 & 7.184 \\
\hline 10 & 0.516 & 1.997 & 0.067 & 6.656 \\
\hline
\end{tabular}

Table 5: Discrimination measures of qualitative traits in dimension1-2

\begin{tabular}{|c|c|c|c|c|c|c|c|c|}
\hline \multicolumn{9}{|c|}{ Discrimination Measures } \\
\hline \multirow{2}{*}{ Variables } & \multicolumn{2}{|c|}{ Dimension } & \multirow{2}{*}{$\begin{array}{l}\text { variables } \\
\text { (continued) }\end{array}$} & \multicolumn{2}{|c|}{ Dimension } & \multirow{2}{*}{$\begin{array}{c}\text { variables } \\
\text { (continued) }\end{array}$} & \multicolumn{2}{|c|}{ Dimension } \\
\hline & 1 & 2 & & 1 & 2 & & 1 & 2 \\
\hline $\mathrm{fr}$ & 0.188 & 0.173 & ceb & 0.133 & 0.602 & Im & 0.048 & 0.025 \\
\hline$s$ & 0.188 & 0.173 & Is & 0.002 & 0.007 & Ir & 0.186 & 0.032 \\
\hline lb & 0.710 & 0.033 & sm & 0.065 & 0.001 & Ic & 0.001 & 0.030 \\
\hline bh & 0.690 & 0.063 & ct & 0.013 & 0.043 & $\mathrm{scl}$ & 0.373 & 0.102 \\
\hline $\mathrm{sp}$ & 0.688 & 0.069 & $\mathrm{rt}$ & 0.175 & 0.078 & $f$ & 0.559 & 0.044 \\
\hline pfs & 0.023 & 0.011 & tre & 0.112 & 0.007 & op & 0.027 & 0.318 \\
\hline $\operatorname{csco}$ & 0.020 & 0.182 & crc & 0.152 & 0.362 & $\mathrm{pc}$ & 0.047 & 0.553 \\
\hline csep & 0.139 & 0.017 & ecr & 0.021 & 0.160 & clv & 0.094 & 0.546 \\
\hline $\operatorname{csex}$ & 0.062 & 0.067 & erp & 0.033 & 0.123 & cal & 0.233 & 0.171 \\
\hline ghs & 0.003 & 0.028 & po & 0.559 & 0.044 & pal & 0.034 & 0.008 \\
\hline \multicolumn{7}{|c|}{ Active Total } & 5.578 & 4.075 \\
\hline \multicolumn{7}{|c|}{$\%$ of Variance } & 18.59 & 13.58 \\
\hline
\end{tabular}

Codes of variables are showed in Table 2. 


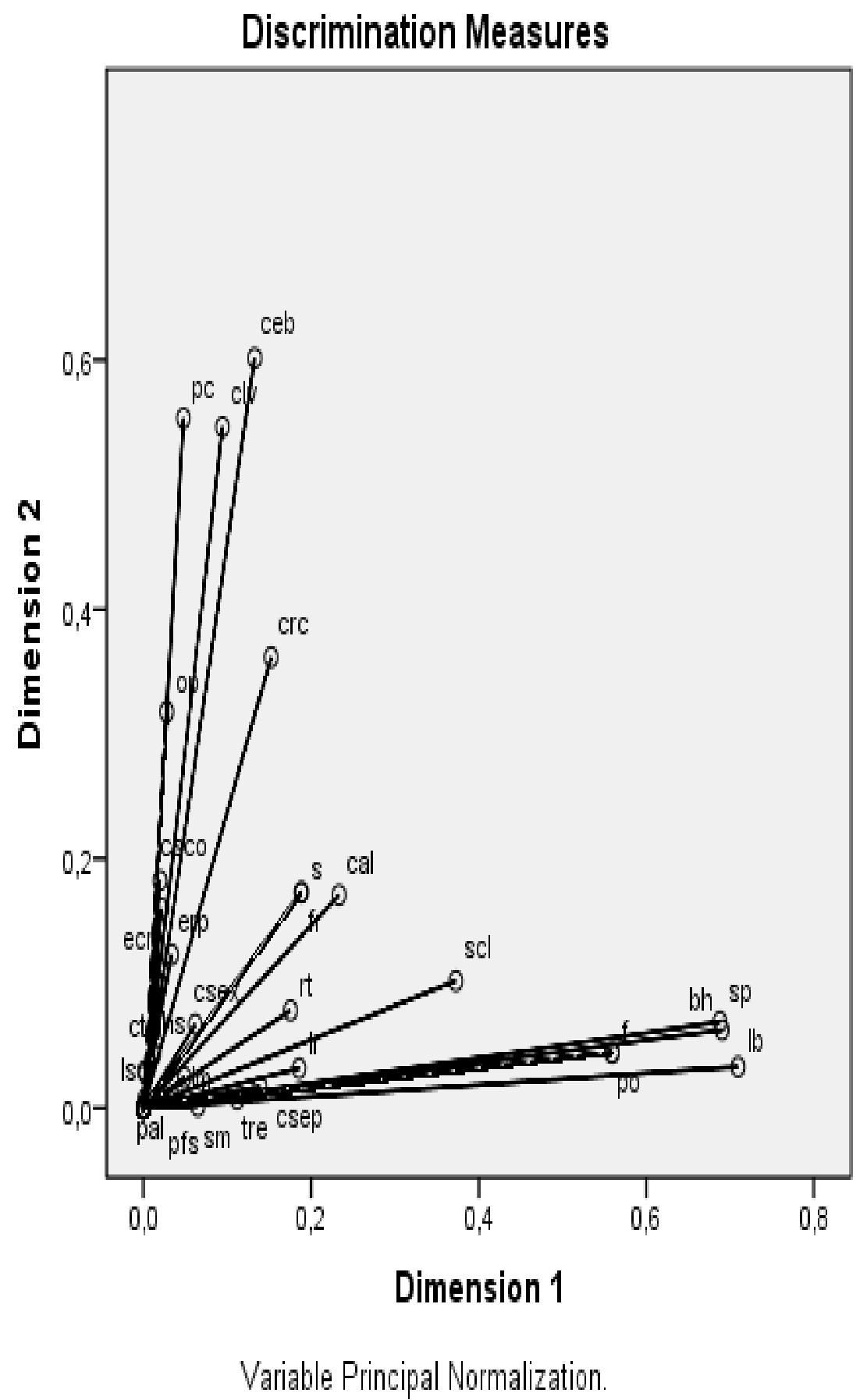

Figure 2: Representation of qualitative traits in the factor plane 1-2. cal: color of apical leaves, pal: pubescence on apical leaves, clv: color of leaf vein, pc: petiole colour, op: orientation of petiole, $f$ : flowering, scl: shape of central leaflet, Ic: leaves color, Ir: leaf retention, Im: lobe margins, po: pollen, ghs: growth habit of stem, ceb: color of end branches of adult plant, csco: color of stem cortex, csep: color of stem epidermis, csex: color of stem exterior, sm: stipule margin, pfs: prominence of foliar scars, Is: length of stipules, fr: fruit, s: seeds, lb: levels of branching, bh: branching habit, sp: shape of plant, erp: extent of root peduncle, crc: color of root cortex, rt: root taste, tre: texture of root epidermis, crp: color of root pulp, ecr: external color of root, ct: cortex thickness. 


\section{Dendogram from 35 qualitative characters}

On the cluster analysis for qualitative traits, the accessions were classified in three groups (Figure 3). The first group comprises of accessions 9, 97, 10, 85, $24,75,48,58,80,60,50,84,28,36,88,95,96,30,64$, $31,71,77,57$ et 87 . The second group includes the accessions 13, 34, 29, 42, 14, 16, 21, 45, 73, 38, 39, 43, $93,94,15,17,35,66,25,86,27,53,47,68,41,72,90$, $37,51,54,92,19,22,20,89,62,67,79$ et 91 . The last group brings together accessions $11,12,65,61,33,59$, $18,44,23,76,56,26,40,55,78,32,46,52,74,63,69$, 70,82 et 83 .

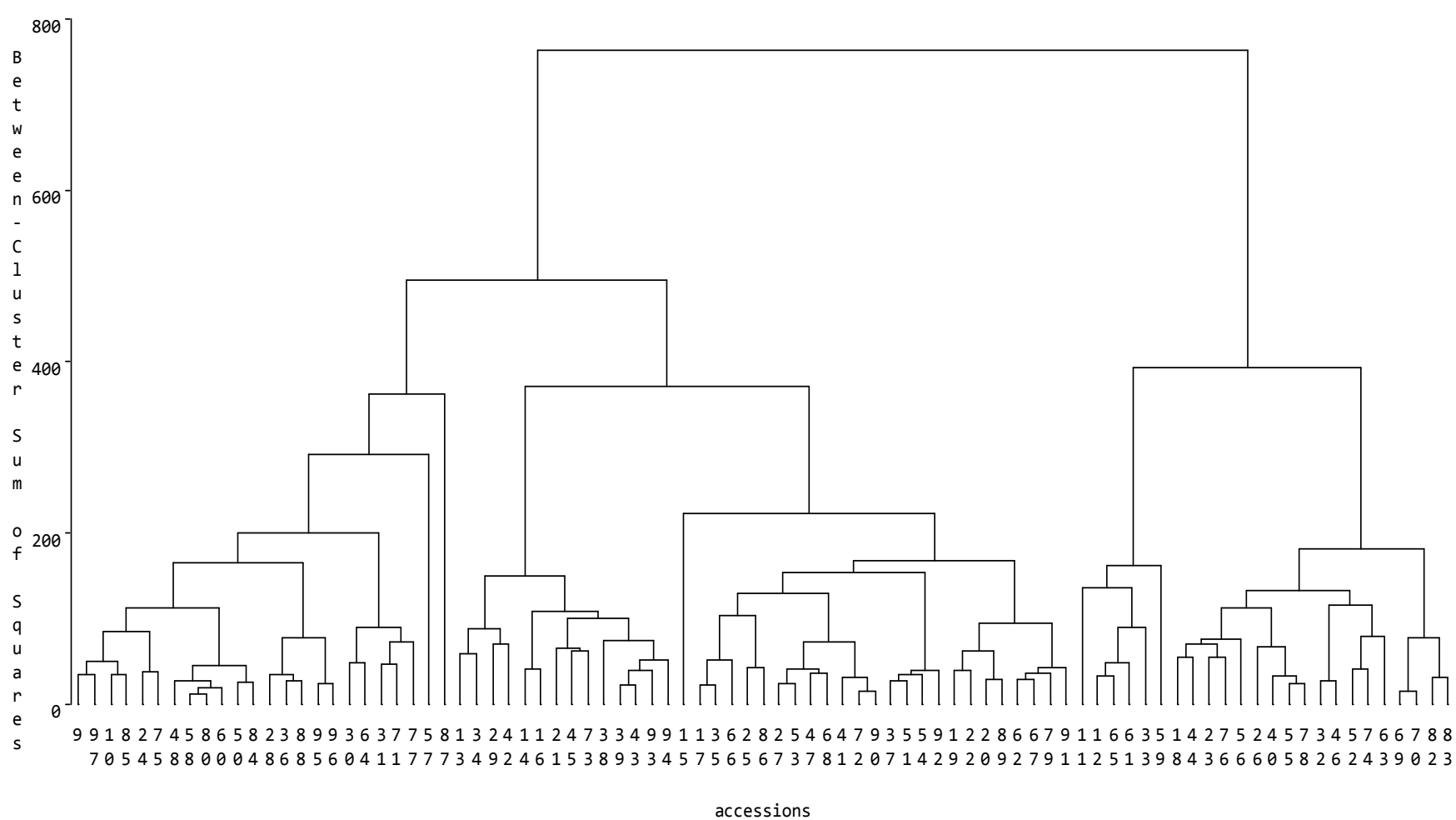

Figure 3: Dendrogram of accessionsderived by UPGMA from qualitative traits. Codes of cultivars are showed in Table 1

\section{Descriptive statistics of quantitative traits}

The cassava accessions revealed variability for the fourteen evaluated quantitative morphological characters (Table 6). The range of values produced were 1.7 to 4.1 $\mathrm{m}$ for plant height, 2 to 22 for the number of fresh storage roots per plant, 2 to 18 for the number of fresh commercial roots per plant, 14 to $30.3 \mathrm{~cm}$ for the length of leaf lobe, 4 to 8.5 for width of leaf lobe, 2.1 to 6.5 for the ratio length/width lobe, 5 to 9 for number of leaf lobes, 14.5 to 36 for petiole length, 1.5 to $17.5 \mathrm{~kg}$ for the fresh root weight, 0.5 to $17 \mathrm{~kg}$ for weight of shoot, 2.3 to $34.5 \mathrm{~kg}$ for total plant biomass and 0.06 to 0.8 for harvest index (Table 6). Coefficients of variation range from $11.85 \%$ (number of leaf lobes) to $55.75 \%$ (weight of shoot). Of the 14 quantitative traits studied, 7 had high coefficients of variation (CV> $20 \%$ ). Seven (7) others exhibit low variations. The variability among the cassava accessions for all quantitative characters was demonstrated by significant differences $(P<0.05)$ (Table $6)$. 
Table 6: Descriptive statistics and ANOVA of quantitative characters

\begin{tabular}{|c|c|c|c|c|c|c|c|}
\hline Variables & Means & SD & Min & Max & $\mathrm{V}$ & $\mathrm{CV}$ & $p$ \\
\hline Plant height (ph) & 2.87 & 0.54 & 1.70 & 4.10 & 0.30 & 19.01 & $0.000^{\star \star \star}$ \\
\hline Height to first branching (hfb) & 1.39 & 0.61 & 0.00 & 3.56 & 0.38 & 44.55 & $0.000^{\star \star \star}$ \\
\hline Angle of branching $(a b)$ & 48.48 & 16.68 & 0.00 & 67.50 & 278.11 & 34.40 & $0.000^{\star \star \star}$ \\
\hline Length of leaf lobe (III) & 23.15 & 3.26 & 14.00 & 30.30 & 10.64 & 14.09 & $0.000^{\star \star \star}$ \\
\hline Width of leaf lobe (wll) & 6.33 & 0.92 & 4.00 & 8.50 & 0.86 & 14.63 & $0.000^{\star \star \star}$ \\
\hline Ratio length/width lobe $(r)$ & 3.72 & 0.65 & 2.10 & 6.50 & 0.43 & 17.65 & $0.000^{\star \star \star}$ \\
\hline Number of leaf lobes (nll) & 7.35 & 0.87 & 5.00 & 9.00 & 0.76 & 11.85 & $0.001^{\star *}$ \\
\hline Petiole length (pl) & 25.59 & 4.51 & 14.50 & 36.00 & 20.42 & 17.66 & $0.000^{\star \star \star}$ \\
\hline Number of storage roots (nsr) & 7.61 & 3.14 & 2.00 & 22.00 & 9.86 & 41.27 & $0.000^{\star \star \star}$ \\
\hline Number of commercial roots (ncr) & 9.39 & 3.81 & 2.00 & 18.00 & 14.54 & 40.62 & $0.000^{\star \star \star}$ \\
\hline Root yield (ry) & 5.05 & 2.29 & 1.50 & 17.50 & 5.28 & 45.55 & $0.000^{\star \star \star}$ \\
\hline Weight of shoot (ws) & 4.47 & 2.48 & 0.50 & 17.00 & 6.20 & 55.75 & $0.000^{\star \star \star}$ \\
\hline Total plant biomass (tpb) & 9.49 & 4.42 & 2.30 & 34.50 & 19.59 & 46.65 & $0.000^{\star \star *}$ \\
\hline Harvest index (hi) & 0.54 & 0.09 & 0.06 & 0.80 & 0.01 & 17.89 & $0.000^{\star \star \star}$ \\
\hline
\end{tabular}

SD: standard deviation, V: variance, CV: coefficient of variation, ${ }^{* *}$ : Significant at a 0.01 probability level, ***: significant at a 0.001 probability level.

\section{Correlation matrix of quantitative traits}

The correlation table shows that plant height was significantly and positively correlated to all the quantitative traits, except harvest index where it is significantly and negatively correlated (Table 7 ). Height to first branching is very highly significantly $(p<0.001), r^{2}$ : 0.618 ) correlated with angle of branching and width of leaf lobe $\left(p<0.01, r^{2}: 0.186\right)$. A very highly significant difference $(p<0.001)$ was observed between width and length of leaf lobe and ratio length/width lobe (Table 5). Length of leaf lobe is very highly significantly $(p<0.001)$ correlated to width of leaf lobe $\left(r^{2}: 0.272\right)$, ratio length/width lobe $\left(r^{2}: 0.524\right)$, petiole length $\left(r^{2}: 0.316\right)$, number of storage roots per plant $\left(r^{2}: 0.311\right)$, number of commercial roots per plant $\left(r^{2}: 0.316\right)$, root yield $\left(r^{2}\right.$ : $0.250)$, weight of shoot $\left(r^{2}: 0.278\right)$, total plant biomass $\left(r^{2}: 0.279\right)$ and very significantly $(p<0.01)$ and negatively correlated with the harvest index $\left(r^{2}:-0175\right)$. The root yield (Table 5$)$ is very highly $(p<0.001)$ correlated to number of storage roots $\left(r^{2}: 0.619\right)$, number of commercial roots per plant $\left(r^{2}: 0.664\right)$, weight of shoot $\left(r^{2}: 0.729\right)$, total plant biomass $\left(r^{2}: 0.925\right)$, petiole length $\left(r^{2}: 0.293\right)$ and length of leaf lobe $\left(r^{2}: 0.250\right)$. 
Table 7: Pearson correlation matrix of 14 quantitative characters

\begin{tabular}{|c|c|c|c|c|c|c|c|c|c|c|c|c|c|c|}
\hline & $\mathrm{ph}$ & $\mathrm{hfb}$ & $A b$ & III & wll & $r$ & $\mathrm{nll}$ & $\mathrm{pl}$ & $\mathrm{nsr}$ & $\mathrm{ncr}$ & ry & hi & ws & $\mathrm{tpb}$ \\
\hline $\mathrm{ph}$ & 1 & & & & & & & & & & & & & \\
\hline $\begin{array}{l}\text { hf } \\
b\end{array}$ & $\underset{*}{0,144}$ & 1 & & & & & & & & & & & & \\
\hline$a b$ & $-\underset{* \star *}{-0,255}$ & $\begin{array}{c}0,61 \\
8 \\
\star \star \star\end{array}$ & 1 & & & & & & & & & & & \\
\hline III & $\underset{* \star * *}{0,409}$ & $\begin{array}{c}0,08 \\
5 \\
\text { ns }\end{array}$ & $\begin{array}{c}- \\
0,03 \\
0 \\
\text { Ns }\end{array}$ & 1 & & & & & & & & & & \\
\hline wll & $\underset{* *}{0,190}$ & $\begin{array}{c}0,18 \\
6 \\
\star *\end{array}$ & $\begin{array}{c}0,15 \\
0 \\
*\end{array}$ & $\begin{array}{c}0,27 \\
2 \\
\star \star \star\end{array}$ & 1 & & & & & & & & & \\
\hline$r$ & $\underset{* \star}{0,178}$ & $\begin{array}{c}- \\
0,06 \\
8 \\
\text { ns }\end{array}$ & $\begin{array}{c}- \\
0,16 \\
9 \\
* *\end{array}$ & $\begin{array}{c}0,52 \\
4 \\
\star \star \star\end{array}$ & $\begin{array}{c}- \\
0,51 \\
8 \\
\star \star \star\end{array}$ & 1 & & & & & & & & \\
\hline nll & $\underset{* \star}{0,184}$ & $\begin{array}{c}0,04 \\
1 \\
\text { ns }\end{array}$ & $\begin{array}{c}- \\
0,05 \\
3 \\
\text { Ns }\end{array}$ & $\begin{array}{c}0,06 \\
8 \\
\text { ns }\end{array}$ & $\begin{array}{c}0,19 \\
2 \\
\star \star\end{array}$ & $\begin{array}{c}- \\
0,05 \\
6 \\
\mathrm{~ns}\end{array}$ & 1 & & & & & & & \\
\hline $\mathrm{pl}$ & $\underset{\star \star \star \star}{0,372}$ & $\begin{array}{c}0,04 \\
5 \\
\text { ns }\end{array}$ & $\begin{array}{c}- \\
0,17 \\
1 \\
* *\end{array}$ & $\begin{array}{c}0,31 \\
6 \\
\star \star \star\end{array}$ & $\begin{array}{c}0,18 \\
3 \\
* *\end{array}$ & $\begin{array}{c}0,10 \\
3 \\
\text { ns }\end{array}$ & $\begin{array}{c}0,35 \\
9 \\
* * *\end{array}$ & 1 & & & & & & \\
\hline $\begin{array}{c}\text { ns } \\
r\end{array}$ & $\underset{\star \star}{0,210}$ & $\begin{array}{c}0,09 \\
4 \\
\mathrm{~ns}\end{array}$ & $\begin{array}{c}0,00 \\
4 \\
\mathrm{Ns}\end{array}$ & $\begin{array}{c}0,31 \\
1 \\
\star \star \star\end{array}$ & $\begin{array}{c}0,13 \\
6 \\
*\end{array}$ & $\begin{array}{c}0,13 \\
0 \\
*\end{array}$ & $\begin{array}{c}0,04 \\
8 \\
\text { ns }\end{array}$ & $\begin{array}{c}0,26 \\
3 \\
\star \star \star\end{array}$ & 1 & & & & & \\
\hline $\begin{array}{c}\mathrm{nc} \\
\mathrm{r}\end{array}$ & $\underset{* *}{0,186}$ & $\begin{array}{c}0,05 \\
1 \\
\mathrm{~ns}\end{array}$ & $\begin{array}{c}0,02 \\
0 \\
\mathrm{Ns}\end{array}$ & $\begin{array}{c}0,31 \\
6 \\
\star \star \star\end{array}$ & $\begin{array}{c}0,16 \\
0 \\
*\end{array}$ & $\begin{array}{c}0,07 \\
6 \\
\mathrm{~ns}\end{array}$ & $\begin{array}{c}0,04 \\
7 \\
\text { ns }\end{array}$ & $\begin{array}{c}0,27 \\
0 \\
\star \star \star\end{array}$ & $\begin{array}{c}0,86 \\
4 \\
\star \star \star\end{array}$ & 1 & & & & \\
\hline ry & $\underset{*}{0,151}$ & $\begin{array}{c}- \\
0,09 \\
5 \\
\text { ns } \\
\end{array}$ & $\begin{array}{c}- \\
0,03 \\
1 \\
\text { Ns }\end{array}$ & $\begin{array}{c}0,25 \\
0 \\
\star \star \star\end{array}$ & $\begin{array}{c}0,10 \\
7 \\
\mathrm{~ns}\end{array}$ & $\begin{array}{c}0,02 \\
6 \\
\mathrm{~ns}\end{array}$ & $\begin{array}{c}0,01 \\
1 \\
\mathrm{~ns}\end{array}$ & $\begin{array}{c}0,29 \\
3 \\
\star \star \star\end{array}$ & $\begin{array}{c}0,61 \\
9 \\
\star \star \star\end{array}$ & $\begin{array}{c}0,66 \\
4 \\
\star \star \star\end{array}$ & 1 & & & \\
\hline hi & $\underset{* \star *}{-0,240}$ & $\begin{array}{c}- \\
0,11 \\
2 \\
\mathrm{~ns}\end{array}$ & $\begin{array}{c}- \\
0,17 \\
5 \\
\star \star\end{array}$ & $\begin{array}{c}- \\
0,17 \\
5 \\
\star \star\end{array}$ & $\begin{array}{c}- \\
0,07 \\
1 \\
n s\end{array}$ & $\begin{array}{c}- \\
0,10 \\
7 \\
\text { ns }\end{array}$ & $\begin{array}{c}- \\
0,14 \\
6 \\
*\end{array}$ & $\begin{array}{c}- \\
0,06 \\
1 \mathrm{~ns}\end{array}$ & $\begin{array}{c}- \\
0,07 \\
9 \\
\text { ns }\end{array}$ & $\begin{array}{c}- \\
0,03 \\
3 \\
n s\end{array}$ & $\begin{array}{c}0,05 \\
8 \\
\text { ns }\end{array}$ & 1 & & \\
\hline $\begin{array}{l}\text { W } \\
\mathrm{s}\end{array}$ & $\underset{* \star *}{0.254}$ & $\begin{array}{c}0.01 \\
8 \\
\mathrm{~ns} \\
\end{array}$ & $\begin{array}{c}0.12 \\
2 \\
*\end{array}$ & $\begin{array}{c}0.27 \\
8 \\
\star * \star \\
\end{array}$ & $\begin{array}{c}0.11 \\
3 \\
\mathrm{~ns} \\
\end{array}$ & $\begin{array}{c}0.07 \\
9 \\
\mathrm{~ns} \\
\end{array}$ & $\begin{array}{c}0.09 \\
2 \\
\text { ns } \\
\end{array}$ & $\begin{array}{c}0.25 \\
2 \\
\star \star \star \\
\end{array}$ & $\begin{array}{c}0.52 \\
6 \\
\star * * \\
\end{array}$ & $\begin{array}{c}0.53 \\
5 \\
\star * \star \\
\end{array}$ & $\begin{array}{c}0.72 \\
9 \\
\star \star \star \\
\end{array}$ & $\underset{* \star \star}{-}$ & 1 & \\
\hline $\begin{array}{l}\text { tp } \\
b\end{array}$ & 0.221 & $\begin{array}{c}- \\
0.03 \\
5 \\
n s\end{array}$ & $\begin{array}{c}0.05 \\
0 \\
\text { ns }\end{array}$ & $\begin{array}{c}0.27 \\
9 \\
\star \star \star\end{array}$ & $\begin{array}{c}0.11 \\
0 \\
\mathrm{~ns}\end{array}$ & $\begin{array}{c}0.06 \\
0 \\
\text { ns }\end{array}$ & $\begin{array}{c}0.06 \\
0 \\
\text { ns }\end{array}$ & $\begin{array}{c}0.29 \\
0 \\
\star \star \star\end{array}$ & $\begin{array}{c}0.61 \\
8 \\
\star \star \star\end{array}$ & $\begin{array}{c}0.64 \\
5 \\
\star \star \star\end{array}$ & $\begin{array}{c}0.92 \\
5 \\
\star \star *\end{array}$ & $0 . \overline{x_{* \star *}}$ & $\begin{array}{c}0.92 \\
8 \\
\star \star \star\end{array}$ & 1 \\
\hline
\end{tabular}

${ }^{*}: p<0.05$ (significant difference), ${ }^{* *}: p<0.01$ (highly significant difference), ${ }^{* * *}: p<0.001$ (very high significant difference), ns: non-significant. III:length of leaf lobe, wll: width of leaf lobe, $r$ : ratio length/width lobe, nll: number of leaf lobes, pl: petiole length, ph: plant height, hfb: height to first branching, ab: angle of branching, nsr: number of storage roots, ncr: number of commercial roots per plant, ry: root yield, ws: weight of shoot; tpb: total plant biomass, 


\section{Representation of variables of quantitative traits}

According to the Kaiser criterion, dimensions (axes) with its own value greater than 1 must be kept for proper representation of variables. These dimensions are provided by the PCA. According to the criterion of the elbow, on the scree of values, there is a breakage (elbow or knee flexion) followed by a steady decline. Then the axes are selected before the breakage. According to these two criteria, the first five axes are preserved. Their values are respectively 4.394, 1.921, $1.742,1.497$ and 1.217 (Table 8). The first five principal components best explains the diversity of cassava accessions. The five main components represent $76.90 \%$ share of information. The first factorial plane (12) contains $31.40 \%$ of the original variance data (Table
8, Figure 4). The variables significantly correlated with axe 1 are: total plant biomass $(90.5 \%)$, shoot weight (85.4\%), root yield $(83.1 \%)$, number of commercial roots $(80.1 \%)$, number of storage roots $(79 \%)$, length of leaf lobe $(51.5 \%)$ and petiole length (47.4\%). The variables significantly correlated to the axe 2 are: angle of branching $(78.6 \%)$, height to first branching (66.8\%), ratio length/width lobe (-63.5\%) and width of leaf lobe $(54.4 \%)$. The variables significantly related to axe 3 are: plant height $(60.9 \%)$, length of leaf lobe $(48.8 \%)$, number of leaf lobes (48.5\%) and petiole length (44.5\%). The variables significantly correlated to the axe 4 are: ratio length/width lobe $(-62 \%)$ and width of leaf lobe $(51 \%)$. The variables significantly correlated to the axe 5 are: harvest index (66\%) (Table 8, Figure 4).

Table 8: Coefficient and vector association with the first 5 principal components (PC)

\begin{tabular}{|l|c|c|c|c|c|}
\hline \multirow{2}{*}{ Characteristics } & \multicolumn{5}{|c|}{ Principal components (PC) } \\
\cline { 2 - 6 } & PC1 & PC2 & PC3 & PC4 & PC5 \\
\hline Eigenvalue & 4.394 & 1.921 & 1.742 & 1.497 & 1.217 \\
\hline Proportion (\%) & 31.385 & 13.721 & 12.445 & 10.693 & 8.695 \\
\hline Cumulative (\%) & 31.385 & 45.107 & 57.551 & 68.244 & 76.939 \\
\hline \multicolumn{7}{|c|}{ Coefficient vector } \\
\hline Plant height (ph) & 0.423 & -0.169 & $\mathbf{0 . 6 0 9}$ & 0.071 & 0.008 \\
\hline Height to first branching (hfb) & 0.067 & $\mathbf{0 . 6 6 8}$ & 0.301 & -0.340 & 0.371 \\
\hline Angle of branching (ab) & 0.009 & $\mathbf{0 . 7 8 6}$ & -0.060 & -0.438 & 0.139 \\
\hline Length of leaf lobe (III) & $\mathbf{0 . 5 1 5}$ & -0.207 & $\mathbf{0 . 4 8 8}$ & -0.222 & 0.334 \\
\hline Width of leaf lobe (wll) & 0.238 & $\mathbf{0 . 5 4 4}$ & 0.295 & $\mathbf{0 . 5 1 0}$ & 0.101 \\
\hline Ratio length/width lobe (r) & 0.175 & $-\mathbf{0 . 6 3 5}$ & 0.235 & $\mathbf{- 0 . 6 2 0}$ & 0.195 \\
\hline Number of leaf lobes (nll) & 0.172 & 0.079 & $\mathbf{0 . 4 8 5}$ & 0.372 & -0.245 \\
\hline Petiole length (pl) & $\mathbf{0 . 4 7 4}$ & -0.141 & $\mathbf{0 . 4 4 5}$ & 0.333 & 0.070 \\
\hline Number of storage roots (nsr) & $\mathbf{0 . 7 9 0}$ & 0.002 & -0.200 & 0.021 & 0.299 \\
\hline Number of commercial roots (ncr) & $\mathbf{0 . 8 0 1}$ & 0.014 & -0.244 & 0.077 & 0.301 \\
\hline Root yield (ry) & $\mathbf{0 . 8 3 1}$ & -0.054 & -0.395 & 0.139 & 0.029 \\
\hline Weight of shoot (ws) & $\mathbf{0 . 8 5 4}$ & 0.118 & -0.123 & -0.187 & -0.421. \\
\hline Total plant biomass (tpb) & $\mathbf{0 . 9 0 5}$ & 0.033 & -0.280 & -0.027 & -0.204 \\
\hline Harvest index (hi) & -0.314 & -0.205 & -0.339 & 0.425 & $\mathbf{0 . 6 6 0}$ \\
\hline
\end{tabular}




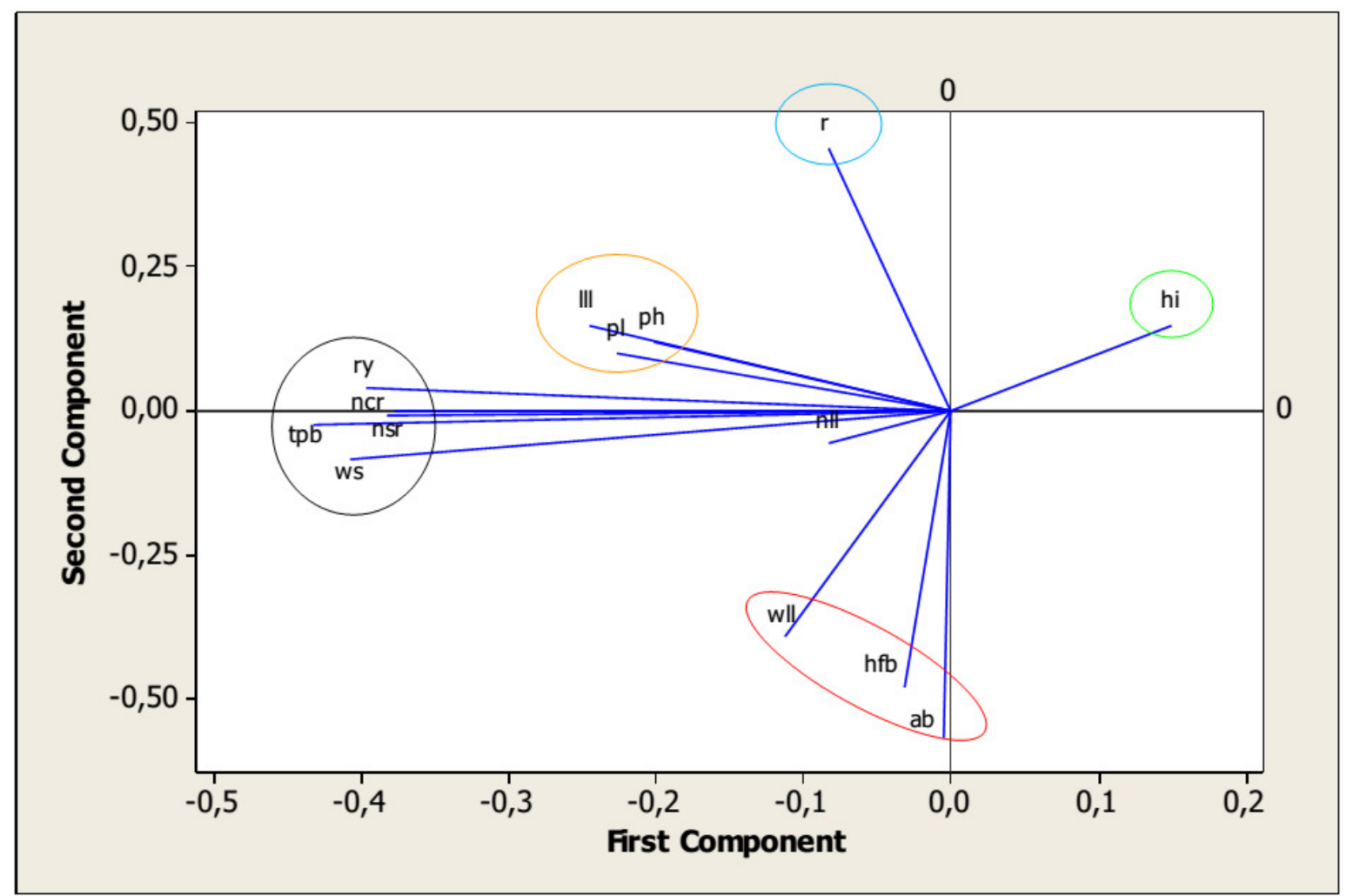

Figure 4: Representation of quantitative variables in the factor plane 1-2. III: length of leaf lobe, wll: width of leaf lobe, r: ratio length/width lobe, nll: number of leaf lobes, pl: petiole length, ph: plant height, hfb: height to first branching, ab: angle of branching, nsr: number of storage roots, ncr: number of commercial roots per plant, ry: root yield, ws: weight of shoot; tpb: total plant biomass, hi: harvest index.

\section{Dendogram from 14 quantitative traits}

Hierarchical classification grouped accessions into three classes almost with the same characteristics as a function of the variables (Figure 5, Table 9). Group 1 consisted mainly of accessions with low yields. The group 2 essentially comprised of middle-yield accessions. The group 3 is mostly composed of highyield accessions. 


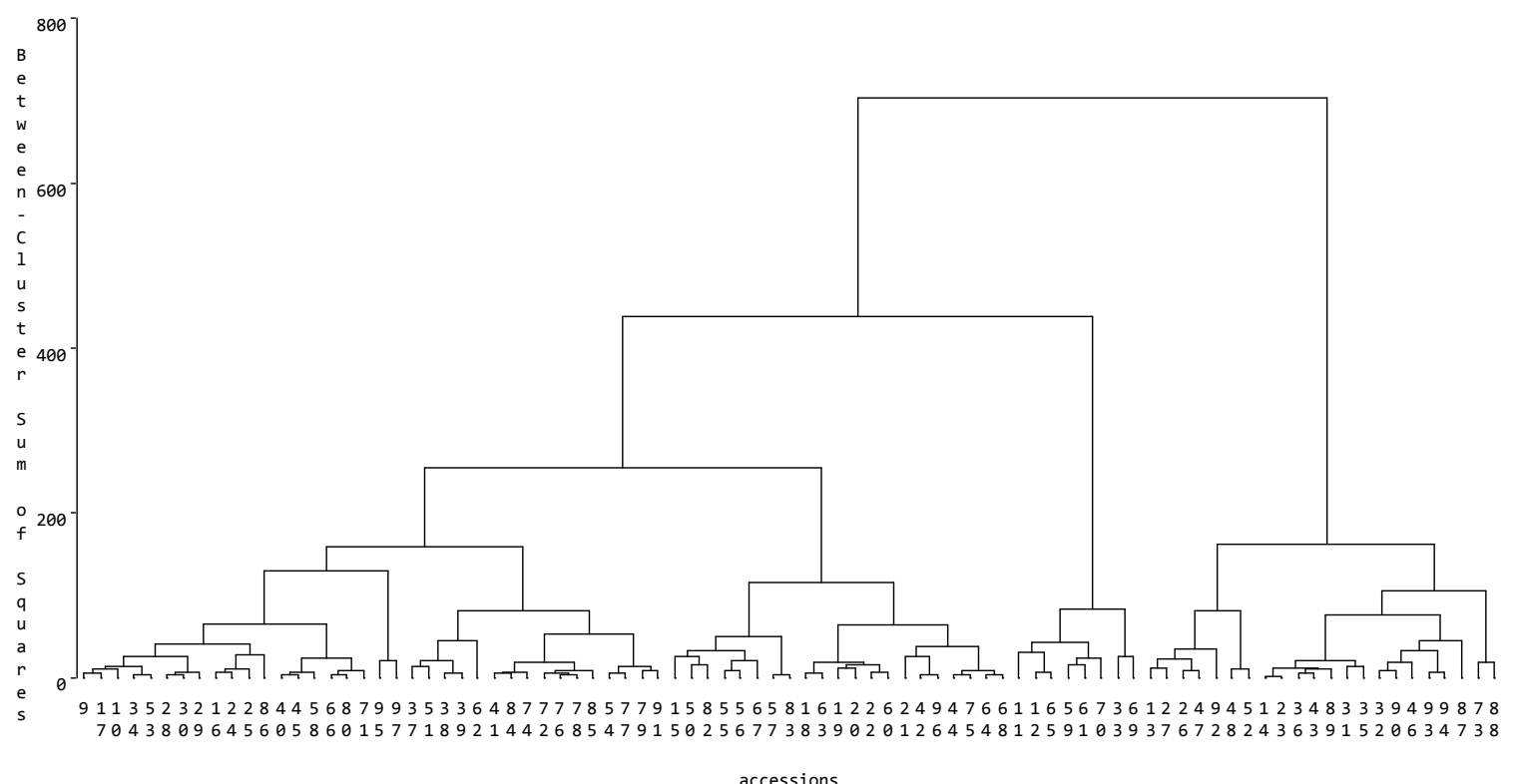

Figure 5: Dendrogram of accessions derived by UPGMA Person correlation coefficient from 14 quantitative traits. Codes of cultivars are showed in Table 1

Table 9: Distribution of cassava accessions in different clusters

\begin{tabular}{|l|l|}
\hline Cluster & Accessions \\
\hline 1 & $\begin{array}{l}9,17,10,34,53,28,30,29,16,24,25,86,40,45,58,66,80,71,95,97,37, \\
\end{array}$ \\
$\begin{array}{l}51,38,39,62,41,84,74,72,76,78,85,54,77,79,91,15,50,82,55,56, \\
67,57,83,18,63,19,20,22,60,21,42,96,44,75,64,68,\end{array}$ \\
\hline 2 & $11,12,65,59,61,70,33,69$ \\
\hline 3 & $\begin{array}{l}13,27,26,47,92,48,52,14,23,36,43,89,31,35,32,90,46,93,94,87, \\
73,88\end{array}$ \\
\hline
\end{tabular}

Codes of cultivars are showed in Table 1.

\section{Accessions classification according to root yield}

Mean structuring tests of Student and Newman-Keuls were used to classify the average of character roots yield (Table 10). According to this classification, seven local accessions (No. 52, 48, 47, 27, 69, 26 and 86) can be selected for the varietal improvement program. 
Table 10: Anova test to classified accessions by root yield

\begin{tabular}{|c|c|c|c|c|c|}
\hline $\mathrm{N}^{\circ}$ acc & Yield * $10^{4}\left(\mathrm{~kg} \mathrm{ha}^{-1}\right)$ & $\mathrm{N}^{\circ}$ acc & Yield $^{*} 10^{4}\left(\mathrm{~kg} \mathrm{ha}^{-1}\right)$ & $\mathrm{N}^{\circ}$ acc & Yield ${ }^{*} 10^{4}\left(\mathrm{~kg} \cdot \mathrm{ha}^{-1}\right)$ \\
\hline 9 & $5.33 \pm 0.57$ cdefghi & 38 & $4.17 \pm 0.76$ cdefghi & 68 & $2.07 \pm 0.11$ \\
\hline 10 & $6.17 \pm 1.25$ cdefghi & 39 & $4.33 \pm 1.44$ cdefghi & 69 & $8.40 \pm 0.69$ \\
\hline 11 & $5.83 \pm 1.25$ cdefghi & 40 & $4.17 \pm 0.76$ cdefghi & 70 & $5.33 \pm 1.04$ cdefghi \\
\hline 12 & $4.50 \pm 0.86$ cdefghi & 41 & $2.50 \pm 0.86$ & 71 & $6.67 \pm 2.08$ cdefgh \\
\hline 13 & $7.50 \pm 0.50 \quad$ cofefg & 42 & $4.00 \pm 1.00$ defghi & 72 & $5.17 \pm 2.36$ cdefghi \\
\hline 14 & $6.83 \pm 1.04$ cdefgh & 43 & $6.67 \pm 3.75$ cdefgh & 73 & $7.50 \pm 0.86 \quad$ cdefg \\
\hline 15 & $3.97 \pm 0.45$ defghi & 44 & $3.07 \pm 0.90 \quad$ fghi & 74 & $2.90 \pm 1.38$ \\
\hline 16 & $6.83 \pm 0.28$ cdefgh & 45 & $4.17 \pm 2.08$ cdefghi & 75 & $3.67 \pm 1.15$ defghi \\
\hline 17 & $4.67 \pm 0.28$ cdefghi & 46 & $6.33 \pm 0.57$ cdefghi & 76 & $3.73 \pm 2.05$ defghi \\
\hline 18 & $4.00 \pm 1.32$ defghi & 47 & $9.00 \pm 0.00$ & 77 & $5.00 \pm 1.73$ cdefghi \\
\hline 19 & $4.50 \pm 0.50$ cdefghi & 48 & $11.33 \pm 4.51$ & 78 & $4.00 \pm 0.00$ defghi \\
\hline 20 & $4.60 \pm 0.36$ cdefghi & 50 & $3.23 \pm 0.25$ & 79 & $5.17 \pm 0.28$ cdefghi \\
\hline 21 & $2.87 \pm 1.00 \quad$ ghi & 51 & $2.42 \pm 0.52$ & 80 & $5.50 \pm 0.86$ cdefghi \\
\hline 22 & $5.40 \pm 0.52$ cdefghi & 52 & $12.67 \pm 4.19$ & 82 & $4.50 \pm 2.78$ cdefghi \\
\hline 23 & $6.07 \pm 0.40$ cdefghi & 53 & $5.17 \pm 0.57$ cdefghi & 83 & $2.33 \pm 0.57$ \\
\hline 24 & $6.17 \pm 2.02$ cdefghi & 54 & $3.83 \pm 0.28$ defghi & 84 & $2.33 \pm 0.28$ \\
\hline 25 & $6.67 \pm 2.25$ cdefgh & 55 & $4.50 \pm 0.50$ cdefghi & 85 & $3.33 \pm 0.57$ \\
\hline 26 & $8.00 \pm 1.00 \quad$ bcdef & 56 & $3.67 \pm 1.15$ defghi & 86 & $8.00 \pm 2.00$ bcdef \\
\hline 27 & $8.67 \pm 0.57$ & 57 & $1.50 \pm 0.00$ & 87 & $5.17 \pm 3.18$ cdefghi \\
\hline 28 & $6.23 \pm 0.75$ cdefghi & 58 & $4.73 \pm 1.55$ cdefghi & 88 & $3.83 \pm 2.75$ defghi \\
\hline 29 & $6.40 \pm 1.44$ cdefghi & 59 & $4.50 \pm 2.78$ cdefghi & 89 & $7.00 \pm 2.29 \mathrm{cdefgh}$ \\
\hline 30 & $7.50 \pm 1.80$ cdefg & 60 & $4.33 \pm 0.57$ cdefghi & 90 & $3.83 \pm 1.44$ defghi \\
\hline 31 & $7.00 \pm 2.29$ cdefgh & 61 & $4.50 \pm 0.50$ cdefghi & 91 & $4.83 \pm 0.28$ cdefghi \\
\hline 32 & $5.17 \pm 1.15$ cdefghi & 62 & $2.07 \pm 0.11$ & 92 & $5.67 \pm 0.57$ cdefghi \\
\hline 33 & $7.17 \pm 1.76$ cdefgh & 63 & $2.33 \pm 0.28$ & 93 & $3.50 \pm 1.50$ \\
\hline 34 & $5.50 \pm 0.50$ cdefghi & 64 & $3.00 \pm 0.50$ & 94 & $5.33 \pm 1.52$ cdefghi \\
\hline 35 & $5.33 \pm 0.57$ cdefghi & 65 & $4.00 \pm 0.86$ defghi & 95 & $4.17 \pm 0.76$ cdefghi \\
\hline 36 & $5.83 \pm 1.52$ cdefghi & 66 & $4.50 \pm 0.86$ cdefghi & 96 & $3.67 \pm 0.57$ defghi \\
\hline 37 & $3.67 \pm 1.52$ defghi & 67 & $3.67 \pm 1.60$ defghi & 97 & $3.67 \pm 0.76$ defghi \\
\hline
\end{tabular}

Codes of cultivars are showed in Table 1. Values followed by the same letters are not significantly different at the 5\%. Acc: Accessions

\section{DISCUSSION}

About $12 \%$ of local accessions had hair on their apical leaves. Indeed, few wild cassava accessions are pubescent; this trait is most often encountered in improved accessions and contributes to their tolerance to pests and diseases. For example, resistant varieties have hair on their base, which prevents harmful insects such as mites.

The first axis of representation of qualitative characters is related to the architecture of the plant while the second axis comprises the distinctive coloration traits. Dendrogram of accessions derived by UPGMA from qualitative traits have given three groups. The variation in traits observed (phenotype) does not only reflect the genetic constitution of the accession. But it also reflects the interaction of the genotype with the environment (genotype $\times$ environment) within which it is expressed (Noerwijati et al., 2013). Phenotypic variance in cassava is higher than genotypic variance for traits of agronomic importance like root yield. The qualitative characteristics are considered as the most important traits to identify a particular plant accession. Qualitative traits are usually genetically controlled. They are therefore less independent to the response of the environment.

Coefficients of variation range from $11.85 \%$ (number of leaf lobes) to $55.75 \%$ (weight of shoot). This result is similar to those of Agre et al. (2016) which found that the number of leaf lobes has the lowest coefficient of variation. Of the 14 quantitative traits studied, 7 had high coefficients of variation. The high coefficients of variation observed for the examined characters indicated the presence of a high heterogeneity within the population characterized that can be exploited for breeding. Shoot weight presents the highest coefficient of variation; it is an important character in the recommendation for planting of cassava accessions. This trait shows the potential to produce stem cuttings and the possibility of using parts of the shoots as protein source in animal feed (Ceballos et al., 2004). There is variability among the cassava accessions for all 
quantitative characters. According to Vieira et al. (2011), this variability could be explained by the presence of improved and unimproved accessions of different origins. Indeed, the characteristics of some local accessions were similar to those of improved varieties produced by IRAD. The farmers could have domesticated and renamed these improved varieties. The difference between these cassava accessions could also be explained by the existence of genotypic difference (Temegne et al., 2015a).

Plant height was significantly correlated to all the quantitative traits. Indeed, Agre et al. (2015) showed that plant height is the principal character that is significantly and positively correlated with the height to first plant branching, the number of roots per plant, the fresh root yield and the number of leaf lobes. The correlation data constitutes an important tool in the selection of characters to include in cassava breeding programs.

The first two components explain $31.40 \%$ of the total cumulative variance. This result is similar of those of Afonso et al. (2014) who found $32.56 \%$ to the first factorial plane. This is justified by the fact that it was included many main component. It can also be explained by the fact that the variance distribution is associated with the nature and number of characters used in the analysis and focuses on the first principal components. For interpretation of factorial axes of quantitative characters, it is observed that the first axe is related to cassava production (yield). The second axe is the axe of the plant habit (plant shape). The third axe is an axe which refers to the dimensions of the plant. The fourth and fifth axes are relative to the distribution of biomass. It follows from the above analysis that the five (5) axes have a fairly precise meaning and refer to specific traits.

Seven local accessions (No. 52, 48, 47, 27, 69, 26 and 86) can be selected for the varietal improvement program according to root yield. Indeed, despite the attacks of pests (mites, mealybugs, African cochineal of roots and tubers) and diseases (mosaic virus cassava, anthracnose, and cassava bacterial blight), these accessions were able to maintain a biomass and a high yield. These accessions may possess the genes that confer tolerance to pests and diseases. The seven best accessions have yields of from 9 to $13 \mathrm{t} / \mathrm{ha}$. Indeed, the works of IRAD (2008) and Temegne et al. (2015a ) show that local cassava varieties have a yield potential ranging between 10-12 t/ha. The work of Agre et al. (2015) in Benin has shown that the best local accession had a yield of $5.8^{*} 10^{4} \mathrm{~kg} / \mathrm{ha}$ (weight of fresh root: $5.8 \mathrm{~kg}$ ). So the best local cassava accession of Cameroon has a yield $\left(17.5^{\star} 10^{4} \mathrm{~kg} / \mathrm{ha}\right)$ three times higher than the highest accession of Benin. Although Cameroonian soils as soils of sub-Saharan African countries is deficient in nutrients (FAO, 2003; Ngome et al., 2013; Temegne et al., 2015b), its nutrient composition is greater compared to the soils of Benin (Mbogne et al., 2015). The majority of low-yielding accessions in roots showed a growth of the aerial part (weight of shoot) more important than that of the underground part (ry). Nutrient translocation would in this case preferentially to the stems at the expense of tuberous roots. The low yield of some accessions can also be explained by their susceptibility to disease and pests. These perturb physiology and reduce normal plant growth.

\section{CONCLUSION}

The aim of this study was to perform agro-morphological characterization of local cassava accessions collected in two agro-ecological zones of Cameroon. The great variability among accessions and ranking them in groups based on agro-morphological characteristics showed that there are opportunities for plant breeding. However, this work should be completed by characterizing cassava accessions in other agro-ecological zones of Cameroon. Molecular characterization of the cassava accessions is also imperative to further refine the characteristics of these accessions and eliminate repeats in the germplasm collection of IRAD.

\section{COMPETING INTERESTS}

The authors declare that they have no competing interests.

\section{AUTHORS' CONTRIBUTIONS}

The author Temegne Nono Carine collected the data and drafted the manuscript. The author Mouafor Boris Igwacho read and corrected the draft of the manuscript. The author Ngome Ajebesone Francis elaborated the data collection protocol, facilitated fieldwork and corrected the draft of the manuscript.

\section{ACKNOWLEDGEMENTS}

The authors appreciate the financial support obtained from C2D PAR project and the Ministry of Scientific Research and Innovation (MINRESI) Cameroon, and also acknowledge the logistical support from IRAD Nkolbisson.

\section{REFERENCES}

Agre AP, Dansi A, Rabbi IY, Battachargee R, Dansi M, Melaku G, Augusto B, Sanni A, Akouegninou A and Akpagana K (2015). Agromorphological characterization of elite cassava (Manihot esculenta Crantz) cultivars collected in Benin. Int. J. Curr. Res. Biosci. Plant Biol. 2(2): 1-14.www.ijcrbp.com.

Afonso SDJ, Ledo CAdaS, Moreira RFC, Silva SdeOe, Leal VDdeJ and Conceição ALdaS (2014). Selection of descriptors in a morphological characteristic considered in cassava accessions by means of 
multivariate techniques. IOSR-JAVS. 7(1): 13-20. www. iosrjournals.org.

Ceballos $\mathrm{H}$, Iglesias CA, Pérez JC and Dixon AGO (2004). Cassava breeding: opportunities and challenges. Plant Molecular Biology 56: 503-516.

FAO (Food and Agriculture Organization) (2000). Défendre la cause du manioc. FAO: Rome. http://www.fao.org/nouvelle/2000/000405-f.htm.

FAO (Food and Agriculture Organization) (2003). Gestion de la fertilité des sols pour la sécurité alimentaire en Afrique subsaharienne. FAO: Rome.

Fukuda WMG, Guevara CL, Kawuki R and Ferguson ME (2010). Selected morphological and agronomic descriptors for the characterization of cassava. International Institute of Tropical Agriculture (IITA): Ibadan (Nigeria).

IRAD (2008). Rapport national sur l'état des ressources phytogénétiques pour l'alimentation et l'agriculture. IRAD: Yaoundé (Cameroun).

Lin MS (1991). Genetic base of japonica rice varieties released in Taiwan. Euphytica 56: 43-46.

Mbogne JT, Temegne CN, Hougnandan P, Youmbi E, Tonfack LB and Ntsomboh-Ntsefong G (2015). Biodiversity of arbuscular mycorrhizal fungi of pumpkins (Cucurbita spp.) under the influence of fertilizers in ferralitic soils of Cameroon and Benin. J. App. Biol. Biotech. 5(3):1-10. DOI:10.7324/jabb.2015.3501.

Ngome AF, Amougou MFC, Tata PI, Ndindeng SA, Mfopou MYC, Mapiemfu-Lamare D and Njeudeng
TS (2013). Effects of cassava cultivation on soil quality indicators in the humid forest of Cameroon. Greener J. Agric. Sci. 3: 451-457. www.gjournals.org.

Noerwijati K, Nasrullah T and Djoko P (2013). Breeding value estimation of fifteen related cassava genotypes using blup. J. Agricult. Biol. Sci. 8(4): 317-321.

Temegne NC, Ngome AF and Fotso KA (2015a). Influence de la composition chimique du sol sur la teneur en éléments nutritifs et le rendement du manioc (Manihot esculenta Crantz, Euphorbiaceae) dans deux zones agro-écologiques du Cameroun. Int. J. Biol. Chem. Sci. 9(6): 2776-2788. DOI : http://dx.doi.org/10.4314/ijbcs.v9i6.21.

Temegne NC, Mbogne TJ, Nbendah P, Youmbi E, Taffouo VD and Ntsomboh-Ntsefong $G$ (2015b). Effect of phosphate deficiency on growth and phosphorus content of three Voandzou (Vigna subterranean (L.) Verdc.) varieties. IOSR JAVS. 8(9): 52-59. DOI: 10.9790/2380-08915259.

Vieira EA, Fialho $J$ de $F$, Faleiro FG, Bellon $G$, da Fonseca KG, Carvalho LJCB, Silva MS, de PaulaMoraes SV, de Oliveira CM and Denke ML (2011). Characterization of sweet cassava accessions based on molecular, quantitative and qualitative data. Crop Breed. Appl. Biotechnol. 11(3). http://dx.doi.org/10.1590/S198470332011000300005.

Volle M (1981). Analyse des données. Economica: Paris. 